\title{
General Status of Food Cheats in Turkey
}

\author{
Fugen Durlu Ozkaya (Corresponding author) \\ Department of Gastronomy and Culinary Arts, Faculty of Tourism, \\ Ankara Haci Bayram Veli University, PO box 06830, Ankara, Turkey \\ E-mail: fugen.ozkaya@hbv.edu.tr \\ Kadir Cetin (Corresponding author) \\ Department of Gastronomy and Culinary Arts, Faculty of Tourism, \\ Ankara Haci Bayram Veli University, PO box 06830, Ankara, Turkey \\ E-mail: kadir.cetin@hbv.edu.tr
}

\begin{abstract}
Objective: Nutrition has an important place in the preservation of public health, raising the living standards and development of the country's economy. In order to ensure food safety and quality, it has determined the principles and procedures regarding the inspection and control services of the materials and materials in contact with food and food and the minimum technical and hygienic conditions and responsibilities of the food enterprises, and has made some recognitions. This study was carried out in order to reveal the lists of the products which are finalized in the official website of the Ministry in accordance with the Article 8 of the By-Law on the Official Control of Food and Feed.

Method: Qualitative research method was adopted in this study which examined the food lists which were confirmed by the Ministry of Food, Agriculture and Livestock between 2013-2018. The data were converted to statistical data by using the content analysis method.

Results: As a result of the content analysis of the lists between 2013-2018, it was determined that a total of 1073 party products were subjected to imitation and adulteration and these products belonged to 815 enterprises. Most of the products made to pretend and adulterated cheese (161 pieces), olive oil (160 pieces), sunflower oil (96 pieces), sausage varieties (91 pieces), yogurt (85 pcs), ready-made dumplings (80 pieces) and honey varieties (65 pieces), reinforcing foods (63 pieces), ready mortar types (51 pieces) and butter varieties (41 pieces).

Discussion and Conclusion: As the awareness of the modern society's feeding patterns, the negative effects of future generations, children and health on the whole, the societies try to learn more about the foods they consume. To reach the most transparent information about foods in the globalized world is becoming the most natural right of being human and law. However, from the start of the commercial production of food, it is known that foodstuffs are exposed to some tricks such as imitation and adulteration from the field to the fork and various arrangements (laws etc.) are made in order to combat these situations. Considering that 1073 party products were imitated and adulterated between 2013-2018, the fact that these products were produced by imitation and adulteration, how long it was produced, how long it was left in the market, how much of it was sold and consumed, prevented the question of the extent of the situation.
\end{abstract}

Keywords: Food safety, imitation, adulteration, food regulation

DOI: $10.7176 /$ JSTR/5-9-07

\section{Giriş}

Toplumu oluşturan bireylerin büyüme, fizyolojik ve zihinsel gelişimlerini sağlama ve yaşamlarını sürdürebilmeleri için beslenmesi ve fiziki ve ekonomik açıdan; yeterli ve sağlıklı bir gıdaya, sürekli ulaşabilmeleri gerekmektedir. Toplumu oluşturan insanın biyolojik bir organizma olarak varlığını devam ettirecek enerjinin sağlanmasını ifade eden beslenme toplum sağlığının korunmasında, yaşam standartlarının yükseltilmesinde, ülke ekonomisinin kalkınmasında önemli bir yere sahiptir. Beslenme işlevini besin elementleri sağlar. Besin elementlerini içeren, işlenmiş ve doğal haldeki yenilebilir, beslenmeye elverişli her tür madde gıda olarak tanımlanmaktadır (Türk Dil Kurumu 2018). 21. yüzyılda dünya nüfusunun hızla artması, ekonomik eşitsizlik, iklim değişikliği, mevcut doğal kaynakların etkin 
kullanılamaması, hızlı kentleşme, çevre kirliliği, küreselleşme gibi birçok faktör gıda tüketimini ve teminini zorlaştırmaktadır. Bu durumda gıda güvenliğini tehdit etmektedir.

Gıda güvenliğinin sağlanamaması ve gıda kaynaklı hastalıklar sağlık sistemine yük getirebilir, toplumun sosyo-kültürel olarak gelişimini engelleyebilir, devletin ulusal ve uluslararası turizm, ticaret ve ekonomisine zarar verebilir. Bu yüzden devletler gıda güvenliğinin, kalitesinin ve güvencesinin sağlanması amacıyla gıda ve gıda ile temasta bulunan madde ve malzemelerin denetim ve kontrol hizmetleri ile gıda işletmelerinin minimum teknik ve hijyenik şartlarına ve sorumluluklarına dair usul ve esasları belirlemiş, bazı kavramların tanımlarını yapmıştır. Bu kapsamda birçok tanım yapılmıştır fakat araştırmanın bütünlüğü ve anlaşıla bilirliği açısından gıda mevzuatı, taklit, tağşiş, gıda güvenliği ve güvencesi kavramlarının tanımlanmasının gerektiği düşünülmektedir.

Gıda mevzuatı, gıda maddelerinin taşıması gereken minimum kalite ve hijyen özelliklerini belirlemek amacıyla uygulamaya konan kanun, yönetmelik ve tebliğlerden oluşan bir kurallar bütünüdür. Gıda mevzuatının hazırlanmasındaki temel amaç, gıda güvenliğini sağlamak, hijyenik ve ekonomik açıdan tüketiciyi korunmaktır (Gıda Güvenliği Ve Kalitesinin Denetimi Ve Kontrolüne Dair Yönetmelik, 2018; Giray, 2007).

Taklit, gıda ürünlerinin şekil, bileşim ve nitelikleri itibariyle yapısında bulunmayan özelliklere sahip gibi veya başka bir ürünün aynısıymış gibi üretilmesi olarak tanımlanmaktadır. Tağşşs, ürünlere temel özelliğini veren içeriğin ve besin değerlerinin kısmen ya da tamamının mevzuata aykırı olarak çıkarılmasını/değiştirilmesini veya aynı niteliğe sahip olmayan başka bir maddenin, o madde yerine aynı maddeymiş gibi katılması olarak tanımlanmaktadır (Gıda Güvenliği ve Kalitesinin Denetimi Ve Kontrolüne Dair Yönetmelik, 2018; Veteriner Hizmetleri, Bitki Sağlığı, Gıda ve Yem Kanunu, 2010). Taklit ve tağşş̧e örnek olarak; kırmızı ete ve et ürünlerine domuz, at, eşek ve kanatlı eti karıştırılması, bal üretiminde mısır şurubuna bal enzimi katılarak, arıya şeker şurubu verilerek veya sahte bal ile gerçeğinin karıştırılması, yoğurdun içine bitkisel yağ veya jelatin eklenmesi verilebilir.

Gıda güvenliği, Birleşmiş Milletler Gıda ve Tarım Örgütü (Food and Agriculture Organization of the United Nations; [FAO]) tarafindan "akut veya kronik olarak tüketici sağlı̆ına zarar verebilecek tehlikelerin tamamı" şeklinde tanımlanmıştır (FAO, 2003). Türkiye'de 27009 sayılı Resmi Gazete' de yayınlanan Gıda Güvenliği ve Kalitesinin Denetimi ve Kontrolüne Dair Yönetmeliği’nde ise "gıdalarda olabilecek fiziksel, kimyasal, biyolojik ve her türlü zararların ortadan kaldırılması için alınan önlemlerin tamamı" şeklinde tanımlanmaktadır (Gıda Güvenliği Ve Kalitesinin Denetimi ve Kontrolüne Dair Yönetmelik, 2018).

Bu araştırmanın amacı, Gıda ve Yemin Resmi Kontrolüne Dair Yönetmeliğinin 8 'inci maddesi gereğince Tarım ve Orman Bakanlığı resmi sitesinde kamuoyu bilgisine sunulan taklit ve tağşiş yapıldığı kesinleşen ürünlerin listesini nitel araştırma yöntemi ile derinlemesine incelemektir. Bakanlık tarafindan yayınlanan listelerde denetim sonucunda taklit veya tağşiş yapıldığı kesinleşen ve toplum sağlığını tehlikeye düşürecek şekilde bozulmuş, değiştirilmiş gıdaları üreten/ithal eden firmanın adı, ürün adı, markası, parti ve/veya seri numarası gibi bilgiler yer almaktadır (Gıda ve Yemin Resmi Kontrollerine Dair Yönetmelik, 2010; Veteriner Hizmetleri, Bitki Sağ lığı, Gıda ve Yem Kanunu, 2010). Ayrıca araştırma, "neyi yiyoruz?" ya da "nasıl besleniyoruz?" gibi sorular ile beslenme biçimini buna göre şekillendiren, farkındalık kazanmaya ve sorgulamaya başlayan modern toplumun gıdalardaki taklit ve tağşş̧ konusunda bilinçlendirilmesi, tüketicinin sağlığını korunması açısından önem arz etmektedir. Buna ek olarak literatürde böyle bir çalışmaya rastlanmamıştır. Bundan dolayı bu çalışmanın 2013-2018 yılları arasında gıdalarda taklit ve tağşişe ilişkin genel bir bakış ortaya koyması açısından da önemli olduğu düşünülmektedir.

\section{Yöntem}

Gıda, Tarım ve Hayvancılık Bakanlığı tarafından 2013-2016 yılları arasında yayınlanan taklit ve tağşiş yapıldığ 1 kesinleşen gıda listelerinin incelenmesi amacıyla yapılan bu çalışmada nitel araştırma yöntemi benimsenmiştir. Nitel araştırmada araştırmacı gözlem, görüşme ve doküman analizi gibi nitel veri toplama yöntemlerini kullanarak, algıların ve olayların doğal ortamda gerçekçi ve bütüncül bir biçimde ortaya koymaya ve yorumlamaya çalışmaktadır (Yıldırım ve Şimşek, 2016).

Nitel yaklaşım çerçevesinde veri toplama tekniği olarak doküman incelenmesi; veri analiz yöntemi olarak da içerik analizinden yararlanılmıştır. Doküman incelemesi, dokümanlara ulaşma, dokümanların orijinalliğinin kontrol edilmesi, dokümanları anlama, doküman verilerini analiz etme ve veriyi kullanma olmak üzere beş aşamadan oluşan, araştırılması hedeflenen olgu veya olgular hakkında bilgi içeren yazılı materyallerin analizini kapsayan veri toplama tekniğidir (Yıldırım ve Şimşek, 2016; 8. Forster, 1995). İçerik analizi ise toplanan verileri açıklayabilecek kavramlarla ilişkilendirme sürecidir. Bu süreç verilerin kodlanması, temaların bulunması, kodların ve temaların düzenlenmesi, bulguların tanımlanması ve yorumlanması olmak üzere dört aşamadan oluşmaktadır (Yıldırım ve Şimşek, 2016).

46 I P a g e 
Gıda ve Yemin Resmi Kontrolüne Dair Yönetmeliğinin 8'inci maddesi gereğince Bakanlık resmi sitesinde 2013-2018 yılları arasında kamuoyu bilgisine sunulan taklit ve tağşiş yapıldı̆̆ı kesinleşen ürün listelerinin tamamına ulaşıldığı varsayılmıştır. Araştırmanın kapsamını Gıda ve Yemin Resmi Kontrolüne Dair Yönetmeliğinin 8'inci maddesi gereğince Bakanlık resmi sitesinde kamuoyu bilgisine sunulan taklit ve tağşiş yapıldığı kesinleşen ürün listeleri oluşturmaktadır. Araştırmanın sınırlıklarını ise doküman taraması ve elde edilen verilerin analizinin 15 Mart 2018 ve 15 Nisan 2018 tarihleri arasinda gerçekleştirilmesi oluşturmaktadır.

Araştırma yöntemi birbirini izleyen ve tamamlayan üç aşamadan oluşmaktadır. İlk aşamada, 15-31 Mart 2018 tarihleri arasında literatür taraması ve Gıda, Tarım ve Hayvancılık Bakanlı̆̆ı'nın resmi sitesinde doküman incelemesi yapılmıştır. İkinci aşamada toplanan verilerin iki farklı uzman tarafından ön incelemesi gerçekleştirilmiş, kod ve temalar oluşturulmuştur. Üçüncü aşamada ise belirlenen kod ve temalara göre veriler uzmanlar tarafindan içerik analizine tabi tutulmuştur. Bu sürecin ardından iki uzman tarafından kodlamalar gözden geçirilmiş ve ana kategoriler altında birleştirilerek tartışmalar sonlandırılmıştır.

\section{Bulgular}

2013-2018 yılları arasında Gıda ve Yemin Resmi Kontrolüne Dair Yönetmeliğinin 8'inci maddesi gereğince Bakanlık resmi sitesinde kamuoyu bilgisine sunulan taklit ve tağşiş yapıldığı kesinleşen ürün listelerinin içerik analizi sonucunda, ürünlere, taklit ve tağşiş nedenlerine ilişkin çeşitli verilere ulaşılmıştır. 2013-2018 yılları arasında taklit ve tağşiş yapılan gıdalara ilişkin veriler Tablo 1'de yer almaktadır.

Tablo 1. 2013-2018 yılları arasında taklit ve tağşiş yapılan bazı gıdalar

\begin{tabular}{|c|c|c|c|c|}
\hline $\begin{array}{l}\text { Ana } \\
\text { Kategori }\end{array}$ & Ürün adı & $\begin{array}{l}\text { Ürün } \\
\text { Sayısı }\end{array}$ & $\begin{array}{l}\text { Tespit edilen } \\
\text { Taklit ve tağşiş }\end{array}$ & n* \\
\hline \multirow{13}{*}{ 离 } & Sucuk çeşitleri & 91 & \multirow{13}{*}{$\begin{array}{l}\text { Tek tırnaklı eti (domuz vb.) } \\
\text { Tükürük bezi } \\
\text { Sakatat } \\
\text { Kanatlı eti } \\
\text { Soya } \\
\text { Deri dokusu }\end{array}$} & \multirow{13}{*}{$\begin{array}{c}52 \\
29 \\
70 \\
133 \\
9 \\
9\end{array}$} \\
\hline & Hazır köfte/kebap çeșitleri & 80 & & \\
\hline & Hazır harç çesitleri & 51 & & \\
\hline & Kiyma & 27 & & \\
\hline & Yemek çeşitleri & 15 & & \\
\hline & Çiğ kırmızı et & 13 & & \\
\hline & Sosis & 6 & & \\
\hline & Hazır tost çeşitleri & 6 & & \\
\hline & Hazır börek çeşitleri & 5 & & \\
\hline & Hazır kavurma çeşitleri & 5 & & \\
\hline & Hazır döner çeşitleri & 4 & & \\
\hline & Salam & 4 & & \\
\hline & Jambon & 2 & & \\
\hline \multirow{5}{*}{ 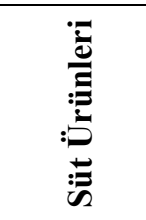 } & Peynir çeşitleri & 161 & \multirow{5}{*}{$\begin{array}{l}\text { Jelatin } \\
\text { Nişasta } \\
\text { Bitkisel yağ } \\
\text { Yabanc1 yağlar }\end{array}$} & \multirow{5}{*}{$\begin{array}{c}43 \\
71 \\
220 \\
42\end{array}$} \\
\hline & Yoğurt çeşitleri & 85 & & \\
\hline & Tereyağ & 41 & & \\
\hline & Sade yağ & 12 & & \\
\hline & Kaymak & 10 & & \\
\hline \multirow{6}{*}{ 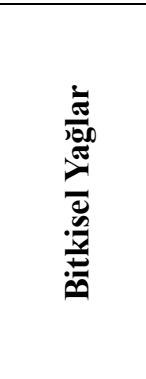 } & & & \multirow{6}{*}{$\begin{array}{l}\text { ECN-42 farkı } \\
\text { Mumsu yapısı } \\
\text { Trans yağ asidi } \\
\text { Sterol kompozisyonu } \\
\text { UV'de özgül soğurma } \\
\text { Yağ asidi etil esterleri } \\
\text { Yağ asitleri kompozisyonu } \\
\text { Misır/Ayçiçek yağından başka } \\
\text { tohum yağları }\end{array}$} & \multirow{6}{*}{$\begin{array}{c}140 \\
18 \\
26 \\
201 \\
41 \\
29 \\
221 \\
98\end{array}$} \\
\hline & Zeytinyağ 1 çeşitleri & 160 & & \\
\hline & & & & \\
\hline & & & & \\
\hline & Ayçiçek yağ1 & 96 & & \\
\hline & Misır yağ1 & 1 & & \\
\hline
\end{tabular}

* Listelerin içerik analizi sonucunda tespit edilen taklit ve tağşiş nedenlerinin sayısı

Tablo 1'de yer alan bilgilere göre et ve et ürünlerinde en çok taklit ve tağşişi yapılan ürün sucuk (91 adet) çeşitleridir. Bunu hazır köfte/kebap çeşitleri ( 80 adet), hazır harç çeşitleri (51 adet) ve kıyma (27 adet) 
takip etmektedir. Laboratuvar sonucunda tespit edilen taklit ve tağşiş verileri incelendiğinde et ve ürünlerinde en çok kanatlı eti (133 adet), sakatat (70 adet) ve tek tırnaklı etine (domuz, eşek, at vb.) (52 adet) rastlanıldı̆̆

Süt ürünlerinde en çok taklit ve tağşiş tespit edilen ürünler peynir çeşitleri (161 adet) ve yoğurt çeşitleri (85 adet); bitkisel yağlarda ise en çok zeytinyağı çeşitleridir (160 adet). Süt ürünlerinde taklit ve tağşiş nedeni olarak bitkisel yağ (220 adet) ve nişasta (71 adet); bitkisel yağ ürünlerinde ise yağ asitleri kompozisyonu (221 adet), sterol kompozisyonu (201 adet) ve ECN-42 fark1 (140 adet) sonucuna ulaşılmıştır. Doğrudan insan tüketimine sunulan ve/veya üretim sonrası diğer ürünlere işlenmek üzere hammadde ya da yarı ürün olarak kullanılan tüm peynirleri kapsayan 29261 sayılı Türk Gıda Kodeksi Peynir Tebliği'ne göre sadece aromalı ve/veya çeşnili taze peynirlerde stabilizör amaçlı olarak nişasta, teknolojinin izin verdiği miktarda kullanılabileceği belirtilmektedir. Bundan dolayı teknolojinin izin verdiği miktardan fazla kullanılmamalıdır. Yağ asitleri ve sterol kompozisyonu yağı çıkarılan her bitkide birbirinden farklıdır. Yağ asitleri ve sterol kompozisyonu analizi yapılarak bitkisel yağlara başka bitkisel yağlar ilave edilip edilmediği tespit edilebilir. Zeytinyağı ve pirina yağlarında bulunan az miktardaki tohum yağlarının (keten, susam vb.) tespiti için kullanılan yönteme ise ECN-42 farkı denir (Anonim, 2018). Tablo 1'in devamı olan Tablo 2'de diğer ürünler, alkollü ve alkolsüz içecekler ilişkin veriler bulunmaktadır.

Tablo 2. 2013-2018 yılları arasında taklit ve tağşiş yapılan bazı gıdalar

\begin{tabular}{|c|c|c|c|c|}
\hline $\begin{array}{l}\text { Ana } \\
\text { Kategori }\end{array}$ & Ürün adı & $\begin{array}{l}\text { Ürün } \\
\text { Sayısı }\end{array}$ & $\begin{array}{l}\text { Tespit edilen } \\
\text { Taklit ve tağsiş }\end{array}$ & $\mathrm{n}^{*}$ \\
\hline \multirow{4}{*}{ 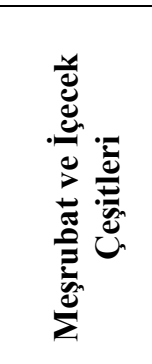 } & $\begin{array}{l}\begin{array}{l}\text { Meyve aromalı içecek } \\
\text { çeşitleri }\end{array} \\
\end{array}$ & 19 & $\begin{array}{l}\text { Hacmen alkol miktarı } \\
\text { Metanol değeri }\end{array}$ & $\begin{array}{l}5 \\
7 \\
\end{array}$ \\
\hline & Kahve/çay çeşitleri & 9 & \multirow{3}{*}{$\begin{array}{l}\text { İlaç etkin maddesi } \\
\text { Sildenafil } \\
\text { Fentolamin } \\
\text { Tadalafil } \\
\text { Kafein }\end{array}$} & \multirow{3}{*}{$\begin{array}{r}34 \\
3 \\
3 \\
3\end{array}$} \\
\hline & Alkollü içecekler & 6 & & \\
\hline & Enerji içeceği & 4 & & \\
\hline \multirow{8}{*}{ 离 } & Takviye edici gıdalar & 63 & \multirow{5}{*}{$\begin{array}{l}\text { Soya } \\
\text { İlaç etkin maddesi } \\
\text { Sildenafil } \\
\text { Tadalafil } \\
\text { Sibutramin }\end{array}$} & \multirow{5}{*}{$\begin{array}{c}79 \\
5 \\
8\end{array}$} \\
\hline & Çikolata & 14 & & \\
\hline & Macun & 13 & & \\
\hline & Şekerli ürün çeşitleri & 2 & & \\
\hline & Tahin & 1 & & \\
\hline & Tarçın & 1 & \multirow{2}{*}{$\begin{array}{l}\text { Buğday nişastası } \\
\text { Yapay gıda boyası }\end{array}$} & 1 \\
\hline & Kırmızı pul biber & 1 & & 2 \\
\hline & Bal çeşitleri & 65 & $\begin{array}{l}\text { Prolin Miktarı } \\
\text { Diastaz Sayıs1 } \\
\text { Fruktoz/Glukoz } \\
\text { C4 Şeker oranı (\%) } \\
\text { Delta 13C Protein ile Delta 13C } \\
\text { bal arasındaki fark }\end{array}$ & $\begin{array}{l}26 \\
25 \\
34 \\
52 \\
55\end{array}$ \\
\hline
\end{tabular}

*Listelerin içerik analizi sonucunda tespit edilen taklit ve tağşiş nedenlerinin sayısı

Tablo 2'de yer alan bilgilere göre alkolsüz içeceklerde meyve aromalı içeceklerde (19 adet) taklit ve tağşiş yapıldığı tespit edilmiş̧ir. Ayrıca çok fazla taklit ve tağşiş yapıldığı tespit edilen bir diğer ürün ise baldır (65 adet). Çikolata, enerji içeceği, kahve, şekerli mamülleri, enerji içeceği, meyve suyu gibi pek çok ürüne viagra'nın etken maddesi olan sildenafil, tadalafil ilave edildiği tespit edilmiştir. 28366 sayılı Türk Gıda Kodeksi Yönetmeliği Bal Tebliği'ne göre bala hiçbir katkı maddesi eklenmemesi gerekmektedir ancak bal da taklit ve tağşiş edilen ürünler arasında yer almaktadır. 
Tablo 3. 2013-2018 yılları arasında taklit ve tağşiş yapıldı̆̆ kesinleşen ürünlerin toplamı

\begin{tabular}{|l|l|l|}
\hline Ana Kategori & $\mathbf{n}$ & $\mathbf{\%}$ \\
\hline Et ve et ürünleri & 309 & 30 \\
\hline Süt ürünleri & 309 & 30 \\
\hline Bitkisel yağlar & 257 & 23 \\
\hline Meşrubat ve içecek çeşitleri & 38 & 3 \\
\hline Diğer ürünler & 160 & 14 \\
\hline Toplam & $\mathbf{1 0 7 3}$ & $\mathbf{\% 1 0 0}$ \\
\hline
\end{tabular}

Tablo 3'e göre 2013-2018 yılları arasında toplam 1073 parti üründe taklit ve tağşiş yapıldığı tespit edilmiştir. Şekil 1'de de yıllara göre Gıda, Tarım ve Hayvancılık Bakanlığının denetimleri sonrasında taklit ve tağşiş yapıldığı kesinleşen gıdaların ana kategori bazında yıllara göre dağılımı verilmiştir.

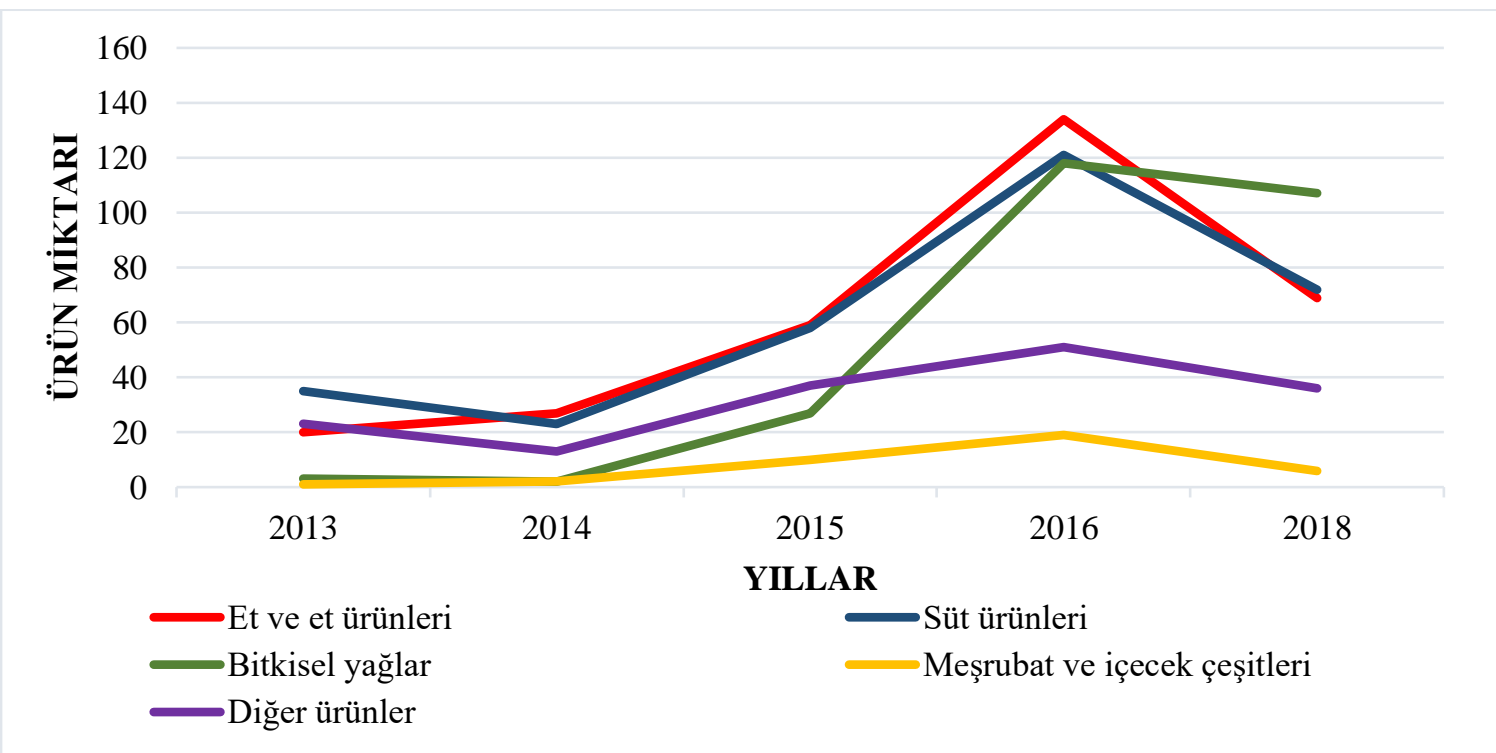

Şekil 1. Taklit ve tağşşs yapıldığı belirlenen gıdaların ana kategori bazında yıllara göre dağılımı

Yıllara göre taklit ve tağşiş yapıldığı belirlenen gıda sayısının en düşük olduğu yıllar 2013-2014 yılları, en yüksek olduğu yıl ise 2016 'dır. Et ve et ürünlerinde, süt ürünlerinde ve bitkisel yağlarda taklit ve tağşş̧ yapılan ürün sayısında 2014 yılından itibaren 2016 yılına kadar hızlı bir artış olduğu görülmektedir. Tablo 4'te 2013-2018 yılları arasında taklit ve tağşiş yapıldığı kesinleşen firmaların yıllara ve ana temalara göre dağılımı verilmektedir.

Tablo 4. Taklit ve tağşiş yapıldığı kesinleşen firmaların yıllara ve ana temalara göre dağılımı

\begin{tabular}{|l|c|c|c|c|c|c|}
\hline \multirow{2}{*}{ Ana Kategori } & \multicolumn{5}{|c|}{ Yıllar } & \multirow{2}{*}{ Toplam } \\
\cline { 2 - 6 } & 2013 & 2014 & 2015 & 2016 & 2018 & \\
\hline Et ve Et Ürünleri & 18 & 26 & 52 & 114 & 47 & $\mathbf{2 5 7}$ \\
\hline Süt Ürünleri & 28 & 20 & 35 & 81 & 42 & $\mathbf{2 0 6}$ \\
\hline Bitkisel Yağlar & 1 & 1 & 14 & 82 & 59 & $\mathbf{1 5 7}$ \\
\hline Meşrubat Ve İçecek Çeşitleri & 1 & 2 & 5 & 18 & 7 & $\mathbf{3 3}$ \\
\hline Diğer Ürünler & 20 & 13 & 31 & 47 & 50 & $\mathbf{1 6 1}$ \\
\hline Yillar Bazında Firma Toplamı & 68 & 63 & 137 & 342 & 205 & $\mathbf{8 1 5}$ \\
\hline
\end{tabular}

Listelerin içerik analizi sonucunda 2013-2018 yılları arasında taklit ve tağşiş yaptığ kesinleşen toplam 815 firmanın 1073 parti üründe taklit ve tağşiş yaptığ 1 tespit edilmiştir. Taklit ve tağşiş yaptığı kesinleşen firma sayısında 2014 yılından itibaren bir artış olduğu görülmektedir. 2014 yılından itibaren bir artışın olması Gıda, Tarım ve Hayvancılık Bakanlığının denetim ağının genişlemesinden ya da denetimlerin 
sıklaşmasından kaynaklı olabileceği düşünülmektedir. Tablo 5'te 2013-2018 yılları arasında farklı yıllarda aynı ya da farklı ürünlerden tekrar taklit ve tağşiş yaptığı kesinleşen firmaların listesi verilmektedir.

Tablo 5. Farklı yıllarda tekrar taklit ve tağşiş yaptığı tespit edilen firmalar

\begin{tabular}{|c|c|c|c|c|c|c|c|c|c|c|c|}
\hline \multirow[b]{2}{*}{ FİRMA ADI } & 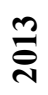 & 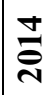 & ) & 룰 & $\frac{\infty}{\vec{\partial}}$ & \multirow{2}{*}{ FIRMA ADI } & 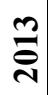 & 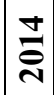 & ก) & ํㅜㄹ & $\frac{\infty}{\partial}$ \\
\hline & \multicolumn{5}{|c|}{\begin{tabular}{|l|} 
ÜRÜN SAYISI \\
\end{tabular}} & & \multicolumn{5}{|c|}{ ÜRÜN SAYISI } \\
\hline $\begin{array}{l}\text { Diltat Gıda İnş. San. Tic. } \\
\text { Ltd. Şti./ } \\
\text { ISTANBUL }^{1}\end{array}$ & 2 & - & 1 & 2 & - & $\begin{array}{l}\text { Kaydaş Gida San. Tic. Ltd. } \\
\text { Sti. } \\
\text { SIVAS }^{3}\end{array}$ & - & - & 1 & 4 & 1 \\
\hline $\begin{array}{l}\text { Nurhamü Gida San. ve Tic. } \\
\text { Ltd. Şti./ } \\
\text { KAYSERI }{ }^{1}\end{array}$ & - & - & 1 & 1 & - & $\begin{array}{l}\text { Gümüş Ticaret Süt ve Süt } \\
\text { Ürünleri/ } \\
\text { ADANA }^{3}\end{array}$ & 1 & - & - & 1 & - \\
\hline $\begin{array}{l}\text { Özmenoğlu Et ve Et } \\
\text { Ürünleri San. Tic. Ltd. Şti./ } \\
\text { KAYSERİ }{ }^{1}\end{array}$ & - & - & 1 & 1 & - & $\begin{array}{l}\text { Hak Süt ve Süt Ürünleri- } \\
\text { Hakkı CILAK Torbalı / } \\
\text { İZMİR }^{3}\end{array}$ & - & - & 1 & 6 & - \\
\hline $\begin{array}{l}\text { Zeka Sucukları Et ve Et } \\
\text { Ürünleri/ Organize Sanayi } \\
\text { Bölgesi Sucukçular Sitesi } \\
\text { AFYONKARAHİSAR }{ }^{\mathbf{1}}\end{array}$ & - & 1 & - & 1 & - & $\begin{array}{l}\text { Mutlu Tolga Gıda İnş. Nak. } \\
\text { Pet. Tur. Hayv. Orm. San. } \\
\text { Tic. Ltd. Şti./ } \\
\text { AFYONKARAHİSAR }{ }^{3}\end{array}$ & 3 & 2 & 1 & 1 & 4 \\
\hline $\begin{array}{l}\text { Süper Tat Pide ve Börek } \\
\text { Salonu - Bilal ŞAHİN/ } \\
\text { İSTANBUL } 1\end{array}$ & - & - & 1 & 1 & - & $\begin{array}{l}\text { Keklik Süt Mam. Gida Paz. } \\
\text { San. Tic. Ltd. Şti./ } \\
\text { IZMIIR }^{\mathbf{3}}\end{array}$ & 1 & - & 1 & - & - \\
\hline $\begin{array}{l}\text { Ak-Ba Et Ür. Tar. Hayv. } \\
\text { Gıda İnş. Nak. San. Tic. Ltd. } \\
\text { Şti./ } \\
\text { KÜTAHYA }^{1}\end{array}$ & - & - & 2 & 1 & - & $\begin{array}{l}\text { İzmir Süt-Yasin Arıkan } \\
\text { İZMIR }^{\mathbf{3}}\end{array}$ & - & - & 1 & 1 & - \\
\hline $\begin{array}{l}\text { Ustam Et ve Et Ürün. Gida } \\
\text { ve İht. Mad. Turz. Maden } \\
\text { San. ve Tic. Ltd. Şti./ } \\
\text { ANKARA }{ }^{1}\end{array}$ & - & 1 & - & 1 & - & $\begin{array}{l}\text { Baltaş Süt Ürünleri-Semai } \\
\text { KARATAŞ } \\
\text { AFYON }^{\mathbf{3}}\end{array}$ & 1 & 1 & 2 & - & - \\
\hline $\begin{array}{l}\text { Özden Et Ür. Paz. Gıda San. } \\
\text { Tic. Ltd. Şti./ } \\
\text { İSTANBUL }^{1}\end{array}$ & - & - & 1 & 1 & - & $\begin{array}{l}\text { Fuat Özer Teks. Pet. Tar. } \\
\text { Gida ve Hayv. Ürün. San. } \\
\text { Tic. Ltd. Şti. } \\
\text { İZMíR }{ }^{3}\end{array}$ & - & - & 1 & 1 & - \\
\hline $\begin{array}{l}\text { Ak Pınar Gıda Süt Hay. İml. } \\
\text { İth.İhr.San.ve Tic. Ltd. Şti./ } \\
\text { KONYA }{ }^{1}\end{array}$ & - & 1 & - & 1 & - & $\begin{array}{l}\text { İzsüt Besicilik Tarım Gıda } \\
\text { İth. San. ve Tic. Ltd. Şti. } \\
\text { İZMİR }{ }^{\mathbf{3}}\end{array}$ & - & 1 & 1 & - & - \\
\hline $\begin{array}{l}\text { Erkan Han Et ve Et } \\
\text { Ürünlerin- } \\
\text { KÜTAHYA }^{\mathbf{1}}\end{array}$ & - & - & 1 & 1 & - & $\begin{array}{l}\text { Sütkon Gıda Tarım Ürn. ve } \\
\text { Day. Tük. Mal. San. Tic. } \\
\text { Ltd. Şti. } \\
\text { KONYA }^{\mathbf{3}}\end{array}$ & - & - & 1 & 4 & - \\
\hline $\begin{array}{l}\text { İkbal Gıda İhtiyaç Maddeleri } \\
\text { İmalat San. İç ve Dış Tic. } \\
\text { A.Ş./ } \\
\text { AFYONKARAHİSAR }{ }^{1}\end{array}$ & - & 1 & - & 1 & - & $\begin{array}{l}\text { Anadolu Eksper Gıda } \\
\text { Sanayi İç ve Dış Tic. Ltd. } \\
\text { Şti. } \\
\text { ANKARA }^{3}\end{array}$ & 1 & - & 1 & - & 1 \\
\hline $\begin{array}{l}\text { Koçlar Gıda Mad. Servis } \\
\text { Hiz. Otomasyon İnş. Nak. } \\
\text { San. ve Tic. Ltd. Şti./ } \\
\text { İSTANBUL } 1\end{array}$ & - & 1 & 1 & - & - & $\begin{array}{l}\text { Aral Gıda San. Tic. Ltd. } \\
\text { Şti./ } \\
\text { KOCAELI }^{3}\end{array}$ & 1 & 1 & - & - & - \\
\hline $\begin{array}{l}\text { Elif Ocakbaşı Gıda ve Et } \\
\text { Ürünleri İnş. Taah. Tic. Ltd. } \\
\text { Şti./ } \\
\text { KIRKLARELI }^{1}\end{array}$ & 1 & 1 & - & - & - & $\begin{array}{l}\text { Akgökseller Gida Süt } \\
\text { Mam. Tarım Ürün. } \\
\text { C.H.O.T. San. Ve Tic. Ltd. } \\
\text { Şti./ } \\
\text { KONYA }^{3}\end{array}$ & - & 1 & - & 2 & 2 \\
\hline
\end{tabular}




\begin{tabular}{|c|c|c|c|c|c|c|c|c|c|c|c|}
\hline \multirow[b]{2}{*}{ FÍRMA ADI } & ᄅั) & 离 & 党 & 它 & $\stackrel{\infty}{\stackrel{\sim}{\sim}}$ & \multirow{2}{*}{ FIRMA ADI } & $\stackrel{m}{\bar{\nu}}$ & 离 & 光 & & $\stackrel{\infty}{\stackrel{\sim}{\sim}}$ \\
\hline & \multicolumn{5}{|c|}{\begin{tabular}{|l} 
ÜRÜN SAYISI \\
\end{tabular}} & & \multicolumn{5}{|c|}{ ÜRÜN SAYISI } \\
\hline $\begin{array}{l}\text { BFM Gıda Tarım } \\
\text { Taşımacılık Teks. San. Tic. } \\
\text { Ltd. Şti./ } \\
\text { AYDIN }^{2} \\
\end{array}$ & - & - & 7 & 3 & - & \begin{tabular}{|l|} 
Beydamla Gıda Boya \\
Kimy. Tarım ve Hayv. Oto. \\
San. Tic. Ltd. Şti./ \\
KONYA $^{\mathbf{3}}$
\end{tabular} & - & 2 & 1 & - & - \\
\hline $\begin{array}{l}\text { Bölükoğlu Yerli ürün Ticaret } \\
\text { AYDIN }^{2}\end{array}$ & 1 & - & - & 1 & - & $\begin{array}{l}\text { Aydoğan Süt Mam. İmal. } \\
\text { İhr. Tic. ve San. Ltd. Şti. } \\
\text { İZMİR }{ }^{3}\end{array}$ & 3 & - & 4 & - & - \\
\hline $\begin{array}{l}\text { Verde Yağ Besin Maddeleri } \\
\text { San. Tic. A.Ş./ } \\
\text { IZMİR }^{2}\end{array}$ & - & - & 2 & 5 & - & $\begin{array}{l}\text { Düziçi Hayat Süt Mam. } \\
\text { Gıda San. Tic. Ltd. Şti./ } \\
\text { ADANA }^{\mathbf{3}}\end{array}$ & 2 & - & - & 1 & - \\
\hline $\begin{array}{l}\text { Güney Tüketim Mal. Tic. } \\
\text { San. Ltd. Şti. / } \\
\text { IZMİR }^{2}\end{array}$ & - & 2 & 1 & 3 & 3 & $\begin{array}{l}\text { Tadaban Gıda San. İç ve } \\
\text { Dış Tic. Ltd. Şti./ } \\
\text { ANKARA }^{\mathbf{3}}\end{array}$ & 3 & 1 & - & - & - \\
\hline $\begin{array}{l}\text { Gürler Süt ve Gıda Ür. Paz. } \\
\text { Tic. Ltd.Şti./ } \\
\text { IZMİR }^{\mathbf{3}}\end{array}$ & - & 1 & - & 1 & - & $\begin{array}{l}\text { Y.E.S. Gaz. Bas. Yay. Öğ. } \\
\text { Evi. Top. Alk. İçkive Meş. } \\
\text { Dağ. Paz. Tic. Ltd. Şti. } \\
\text { BALIKESİ }{ }^{4}\end{array}$ & - & 1 & - & 2 & - \\
\hline $\begin{array}{l}\text { Emre Süt ve Süt Ürünleri } \\
\text { Gıda Hayvancılık San ve } \\
\text { Tic. Ltd. Şti. } \\
\text { IZMİR }{ }^{3}\end{array}$ & - & - & 1 & 10 & 6 & $\begin{array}{l}\text { İntima Gıda Medikal } \\
\text { İthalat ve ve İhracat San. } \\
\text { Ve Tic. Ltd. Şti Çiğli/ } \\
\text { İZMİR } 4\end{array}$ & - & 1 & 7 & 7 & 1 \\
\hline $\begin{array}{l}\text { Emek Süt Ürünleri- Rıfat } \\
\text { SARIKAYA / } \\
\text { IZMİR }^{3}\end{array}$ & - & - & 1 & 3 & - & $\begin{array}{l}\text { NRG Fonksiyonel } \\
\text { İçecekler Ürt. Dağ. Tic. } \\
\text { İSTANBUL } \mathbf{4}\end{array}$ & - & - & 1 & 1 & - \\
\hline $\begin{array}{l}\text { Ünsal Süt ve Süt Mam. } \\
\text { Hayv. Yem Gıda San. Ve Tic. } \\
\text { Ltd. Şti. } \\
\text { KAYSERİ }{ }^{3}\end{array}$ & - & - & 4 & 2 & - & $\begin{array}{l}\text { Tuana Bitkisel Ürün. } \\
\text { Kozm. Gıda İnş. San. Dış } \\
\text { Tic. Ltd. Şti./ } \\
\text { İSTANBUL } 5\end{array}$ & 2 & - & 1 & 1 & - \\
\hline $\begin{array}{l}\text { Demircioğlu Süt ve Süt } \\
\text { Ürünleri-Emre Demirci } \\
\text { KONYA }^{\mathbf{3}}\end{array}$ & - & - & 13 & 18 & 9 & $\begin{array}{l}\text { Can Şifa Baharat Gıda İnş. } \\
\text { Taah. San. Tic. Ltd. Şti. } \\
\text { İzmit / } \\
\text { KOCAELİ } 5\end{array}$ & - & 1 & - & 1 & - \\
\hline $\begin{array}{l}\text { Kaydaş Gıda San. Tic. Ltd. } \\
\text { Şti. } \\
\text { SIVAS }^{3}\end{array}$ & - & - & 1 & 4 & 1 & $\begin{array}{l}\text { Tatlitat Gıda İnş. Teks. İth. } \\
\text { İhr. Turz. San. Tic. Ltd. Şti. } \\
\text { VAN }{ }^{5}\end{array}$ & - & - & 1 & 1 & - \\
\hline $\begin{array}{l}\text { Gümüş Ticaret Süt ve Süt } \\
\text { ürünleri / } \\
\text { ADANA }^{3}\end{array}$ & 1 & - & - & 1 & - & $\begin{array}{l}\text { Kırıntı Baharat Hayv. Tar. } \\
\text { Koz. Gıda Temz. Malz. İnş. } \\
\text { Elek. San. ve Tic.Ltd.Şti./ } \\
\text { KOCAELI } 5\end{array}$ & - & - & 1 & 1 & - \\
\hline $\begin{array}{l}\text { Sütten Gıda Turizm İnş. ve } \\
\text { Oto. San. ve Tic. Ltd. Şti./ } \\
\text { ISTANBUL }^{\mathbf{3}}\end{array}$ & 2 & 1 & - & 1 & - & $\begin{array}{l}\text { Sidra Gıda İnş. Taah. San. } \\
\text { Tic. Ltd. Şti./ } \\
\text { KOCAELI }^{\mathbf{5}}\end{array}$ & - & 1 & 1 & 2 & - \\
\hline $\begin{array}{l}\text { Birsen Güven Gida San. ve } \\
\text { Tic. A.Ş./ } \\
\text { KAYSERI }^{3}\end{array}$ & 1 & 1 & 1 & 2 & - & $\begin{array}{l}\text { Sofram Gida San. Tic. Ltd. } \\
\text { Şti. / } \\
\text { İSTANBUL } 5\end{array}$ & - & - & 2 & 1 & 1 \\
\hline $\begin{array}{l}\text { Narin Süt ve Süt Ürünleri } \\
\text { Gıda Paz. San. ve Tic. Ltd. } \\
\text { Şti./ } \\
\text { KAYSERİ }{ }^{3} \\
\end{array}$ & 2 & 1 & 1 & 4 & 2 & $\begin{array}{l}\text { Beyazlar Gıda Tic. Ltd. Şti. } \\
\text { Gebze/ } \\
\text { KOCAELI } 5\end{array}$ & - & 1 & 1 & - & - \\
\hline
\end{tabular}

${ }^{1}$ Et ve et ürünleri, ${ }^{2}$ Bitkisel yağlar, ${ }^{3}$ Süt ürünleri, ${ }^{4}$ Meşrubat ve içecek çeşitleri, ${ }^{5}$ Diğer ürünler

Listelerin içerik analizi sonucunda 2013-2018 yılları arasında taklit ve tağşiş yaptığı kesinleşen 815 firmadan farklı yıllarda aynı ya da çeşitli ürünlerde taklit ve tağşiş yaptığı tespit edilen 54 firma olduğu

51 | P a g e 
görülmektedir. Bu firmalardan 2 firmanın ürünlerinde 2013-2018 yılları arasında her yıl taklit ve tağşiş yaptığı tespit edilmiştir. Gıda, Tarım ve Hayvancılık Bakanlığının yayınladığı listelerde firma adı, marka, ürünlerin çeşitlerine vb. bilgiler verilmektedir. Fakat taklit ve tağșiş tespit edilen ürünün üretim sürecinde ne kadar üretildiği ve bu ürünlerin ne kadarının piyasaya sürüldüğüne ve satışının gerçekleştiğine dair bilgiler bulunmamaktadır.

\section{Tartışma ve Sonuç}

Modern toplumun beslenme biçimlerinin, gelecek nesillere, çocuklara ve genel olarak sağlığa olumsuz etkilerinin farkındalığı arttıkça toplumlar tükettikleri gıdalar hakkında daha fazla bilgi sahibi olmaya çalışmaktadır. Gün geçtikçe küreselleşen dünyada gıdalar hakkında en şeffaf bilgiye ulaşmak hem insan olmanın hem de kanunun verdiği en doğal haktır. Fakat gıdanın ticari anlamda üretiminin başladığı tarihlerden itibaren gıda maddelerinin, tarladan çatala gelene kadar taklit ve tağşiş gibi bazı hilelere maruz kaldığı ve bu durumlarla mücadele amacıyla çeşitli düzenlemeler (kanun vb.) yapıldı̆̆ bilinmektedir. Bu düzenlemelerin amaçları arasında gıda güvenilirliğini, toplum sağlığı ve menfaatleri ile çevrenin korunması bulunmaktadır. Türkiye'de bunu sağlamak amacıyla oldukça geniş kapsamlı olan 10559 sayılı Veteriner Hizmetleri, Bitki Sağlı̆̆ 1 , Gida ve Yem Kanunu vardır. Bu kanun kapsamında Gıda ve Yemin Resmi Kontrollerine Dair Yönetmeliği gereğince yayımlanan taklit ve tağşiş yaptı̆̆ı kesinleşen gıdaları üreten/ithal eden ya da satan firmanın adı, ürün adı, markası vb. bilgileri içeren listelerin incelenmesi sonucunda 2013-2018 yılları arasında toplam 1073 parti üründe taklit ve tağşiş yapıldı̆̆ 1 saptanmıştır. En çok taklit ve tağşiş yapılan ürünler sırasıyla peynir çeşitleri (161 adet), zeytinyağı (160 adet), ayçicek yağı ( 96 adet), sucuk çeşitleri (91 adet), yoğurt ( 85 adet), hazır köfte çeşitleri ( 80 adet) ve bal çeşitleri (65 adet), takviye edici gıdalar (63 adet), hazır harç çeşitleri (51 adet) ve tereyağı çeşitleridir (41 adet). $\mathrm{Bu}$ ürünlerde tespit edilen taklit ve tağşiş nedenleri olarak peynir, yoğurt ve tereyağ1 çeşitlerinde jelatin, nişasta, yabancı ve bitkisel yağlar; sucuk, hazır köfte ve harç çeşitlerinde tek tırnaklı eti, sakatat, kanatlı eti ve tükürük bezi; zeytinyağı çeşitlerinde ECN-42 fark1, sterol kompozisyonu, yağ asitleri kompozisyonu; bal çeşitlerinde delta $13 \mathrm{C}$ protein ile delta $13 \mathrm{C}$ bal arasındaki fark, $\mathrm{C} 4$ şeker oranı (\%), fruktoz/glukoz; takviye edici gıdalarda ise ilaç etken maddesi ve viagranın etken maddesi olan sildenafil, tadalafil tespit edilmiştir.

2013-2018 yılları arasında 1073 parti üründe taklit ve tağşiş yapıldığı dikkate alındığında dürüst üretici ve tüketici adına durumun vahametini göstermektedir. Fakat bu ürünlerden taklit ve tağșiş yapılarak ne kadar üretildiği, ne kadar süre piyasada kaldığı, ne kadarının satıldığ ve tüketildiği gibi soruların cevaplarının alınamaması durumun boyutlarının ne düzeyde olduğunun ortaya konmasını engellemektedir. Buna ek olarak taklit ve tağşiş yapılan ürünlerin toplu tüketim yapılan yiyecek içecek işletmeleri tarafından satın alınarak kullanılmış olma ihtimali durumu daha da vahim kılmaktadır. Tüm bunlar düşünüldüğünde gıda maddelerinde gerçekleştirilen bu tarz hilelerin toplumun ve gelecek nesillerin sağlı̆̆ını olumsuz yönde etkileyeceği bir gerçektir. Tüketicilerin ve toplumun sağlığını korumak için taklit ve tağşişi engellemek amacıyla ilgili kurumların gerçekleştirdiği denetimler ve halkı bilgilendirici/bilinçlendirici açılamalar son derece önemli ve değerlidir.

Her ne kadar kanunlar tüketicileri korusa da tüketicilere de büyük sorumluluk düşmektedir. Ürünlere taklit ve tağşiş yapıldığ tüketici tarafından tespit edilebilecek bir özellik olmamakla birlikte ürün satın alırken ürünlerin etiket bilgisini mutlaka okumak, dökme olarak tabir edilen menşei belli olmayan veya şüpheli olan gıda maddelerini almamak, markalı ürünleri almak tüketicilerin alabileceği basit önlemlerden bazılarıdır. Ayrıca şüpheli olan gıda maddeleri hakkında Bakanlığa başvuruda bulunarak başka tüketiciler de korunabilir.

\section{Kaynaklar}

Anonim, https://laboratuvar.com adresinden erişilmiştir. Erişim tarihi: 12.05.2018.

FAO. (2003). Assuring Food Safety and Quality. http://www.fao.org/3/a-y8705e.pdf adresinden erişilmiştir. Erişim tarihi: 28.03.2018.

Forster, N. (1995). Analysis the of company documentation. In: C. Cassell \& G. Symon (Ed.), Qualitative Methods in Organizational Research: A Practical Guide 1st Edition. London: Sage.

Gıda Güvenliği Ve Kalitesinin Denetimi Ve Kontrolüne Dair Yönetmelik. (2008, 26, Eylül). Resmi Gazete (Say1: 27009). http://www.resmigazete.gov.tr/eskiler/2008/09/20080926-4.htm adresinden erişilmiştir. Erişim tarihi: 28.03.2018. 
Giray, H. ve Soysal, A. (2007). Türkiye'de Gıda Güvenliği ve Mevzuatı. TSK Koruyucu Hekimlik Bülteni, 6 (6), 485-490.

Gıda ve Yemin Resmi Kontrollerine Dair Yönetmelik. (2010, 11, Hazian). Resmi Gazete (Sayı: 28145). http://www.resmigazete.gov.tr/eskiler/2011/12/20111217-7.htm adresinden erişilmiştir. Erişim tarihi: 28.03.2018.

Türk Dil Kurumu Besin, http://www.tdk.gov.tr/index.php?option=com_gts\&arama=gts\&guid=TDK.GTS.5c3a0aa430c30 7.98614342 adresinden 28.03.2018 tarihinde erişilmiştir.

Veteriner Hizmetleri, Bitki Sağlı̆̆ı, Gıda ve Yem Kanunu. (2010, 11, Haziran). Resmi Gazete (Sayı: 5996). http://www.mevzuat.gov.tr/MevzuatMetin/1.5.5996.pdf adresinden erişilmiştir. Erişim tarihi: 29.03.2018.

Yıldırım, A. ve Şimşek, H. (2016). Sosyal bilimlerde nitel araştırma yöntemleri, Ankara: Seçkin Yayıncilik. 